\title{
Lexical priming in humorous discourse
}

\author{
Andrew Goatly \\ Lingnan University Hong Kong \\ apgoatly@gmail.com
}

\begin{abstract}
This article discusses the relationship between lexical priming and humour. Since incongruity, unpredictability and ambiguity are often associated with humour theory, the article explores the possibility that many jokes or unintended humour depend upon the overriding of lexical priming. Using the Cobuild Bank of English to investigate priming using collocational statistics, the article analyses eight jokes/humorous utterances to demonstrate and test this possibility. While in many cases humour can be explained by cancelling priming, there are some interesting exceptions which are discussed. Finally, an attempt is made to place the idea of cancelling lexical priming in the context of the theory of humour as liberation.
\end{abstract}

Keywords: lexical priming, collocation, jokes, liberation theory of humour.

\section{Introduction}

In this article I begin by emphasising the importance of incongruity, unpredictability and ambiguity in theories of verbal humour. I then sketch lexical priming theory, suggesting that the unexpectedness essential to jokes might be fruitfully theorised in terms of the overriding of priming. I demonstrate that in six jokes or humorous utterances, the unexpectedness and unpredictability of meaning could indeed be explained by the overriding of primings of collocations, semantic set associations, grammatical functions, textual semantic associations, and grammatical category association, suggesting that the latter could involve a more delicate "scope of modification priming". However, two more examples show that not all jokes or humorous utterances can be explained by humour and I raise some questions about the reasons for this. Finally, I relate the phenomenon of cancelling or overriding priming to the theory of humour as liberation.

\section{Humour theories: unpredictability, incongruity, ambiguity}

Q: Which of the following words is the odd one out: greed, anger, malice and depression? A: "And" 
Why does this work as a joke? Because the amount of information carried by the word "and", which is a grammatical rather than a lexical word, is so low, we tend not to consider it as a candidate for the answer to the question. The omission of "and" would apparently hardly reduce the informational content of "greed, anger, malice and depression". Its low information content can be understood by invoking the more technical definition of 'information' which states that it correlates inversely with predictability. There seem to be only two possible words which could predictably substitute in the slot "greed, anger, malice depression": and and or. If that is the case, and if they are both equally likely, and is $50 \%$ predictable and carries 1 bit of information. Paradoxically, of course, the low information content and predictability of "and" in this list makes it highly unpredictable as an answer to the question.

Verbal humour, therefore, seems to depend upon this kind of unpredictability. So much so that another paradox emerges: once we identify the question as belonging to the genre of humorous riddles, we begin to predict an unpredictable answer. So "and" is both predictable and unpredictable within this genre. Consider the alternative answer: "depression-because it's not a human vice, but a state of mind or emotion". This would be externally foregrounded, i.e. unpredictable as the answer to a riddling joke, but internally backgrounded and predictable, especially if this were a test question in school.

Giora's theory of irony and humour is related to predictability and information theory. According to her, well-formed discourse observes the graded-informativeness requirement "that each proposition be more (or at least not less) informative than the one that precedes it." (Giora 1995: 244). Jokes, by contrast, end with a markedly informative message forcing the hearer "to cancel the first unmarked interpretation upon processing the second marked one". So there is no gradual progress in informativeness but "the passage from the least - to the most - informative message is abrupt and surprising" (Giora 1995: 256).

Bergson's suggested three mechanisms of humour-inversion, interference in a series, and repetition (Attardo 1994: 58), and we might relate these mechanisms to predictability and degrees of informativeness. Inversion and interference increase information. But repetition decreases it. I have suggested elsewhere that rather than simply associating humour with increased informativeness, we can say that it depends upon a mismatch between the normal proportion of text/processing and the amount of information derived (Goatly 2012: section 10.2), with shaggy dog stories at the uninformative extreme (cf. Chiaro 1992: 58).

Incongruity and ambiguity seem to be essential to mainstream theories of verbal humour, for example the General Theory of Verbal Humour (GTVH) (Attardo and Raskin 1991, Attardo 2001), which grew out of the Semantic Script Theory of Humour (Raskin 1985), as well as a more recent development in the same incongruity tradition, Ritchie's (2004) Forced Re-interpretation theory of Humour.

Attardo and Raskin's generative model of humour (Attardo and Raskin 1991: 325, Attardo 2001: 71-74) can be diagrammed in Figure 1, where the top four elements are content, and the bottom two are tools. The logical mechanism (LM), false logic (Nash 1985) or pseudo-plausibility (Chafe 2007) is repeatedly emphasised in humour theory: "Every joke must provide a logical or pseudo-logical justification of the absurdity or irreality it postulates", and ambiguity is suggested as one of the logical mechanisms involved (Attardo and Raskin 1991: 307). In the end, this ambiguity will always stem from the script oppositions at the head of the generative model.

Script oppositions and the resulting ambiguity exploited in the logical mechanism also have to be reflected in the NS/LA, the organizational properties of humour texts. In particular we should note the phenomenon of double cohesion. Attardo (1994: 68-9) shows how redundant or repeated semantic categories establish isotopies or coherence in texts (1994: 76), and that the defining feature of jokes is that they create a variation or opposition of 
isotopies, a kind of double coherence. The double coherence and resulting ambiguity reflect the two opposed or incongruous scripts (SO).

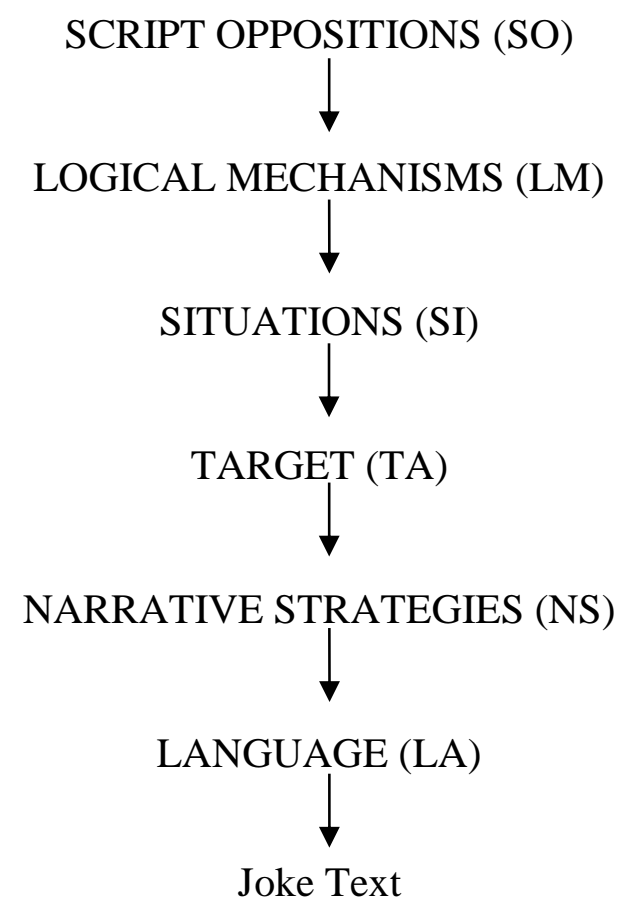

Figure 1. A generative model for jokes

Ritchie's Forced Reinterpretation model (2004) also highlights script oppositions, incongruity and ambiguity. "The set-up has two different interpretations, but one [SU1], is much more obvious to the audience, who do not become aware of the other meaning, [SU2]. The meaning of the punchline $[P L]$ conflicts with this obvious interpretation, but is compatible with, or even evokes, the other, hitherto hidden, meaning [SU2]. The meaning of the punchline can be integrated with the hidden meaning [SU2] to form a consistent interpretation $[I]$ which differs from the first obvious interpretation" (Ritchie 2004: 59). Furthermore, these elements have the following properties:

OBVIOUSNESS: $\quad S U 1$ is more likely than $S U 2$ to be noticed by the reader

CONFLICT: $\quad P L$ does not make sense with $S U 1$.

COMPATIBILITY: $\quad P L$ does make sense with $S U 2$.

CONTRAST: there is some significant difference between SU1 and SU2 (or possible $S U 1$ and $I$ )

INAPPROPRIATENESS: $I$ is inherently odd, eccentric or preposterous, or is taboo, in that it deals with matters not conventionally talked of openly, such as sexual or lavatorial matters, or forbidden political sentiments. These differ in terms of which norms are being flouted: those of everyday logic - leading to absurdity - or those of socially acceptable discourse - leading to taboo effects (Ritchie 2004: $61)$.

Crucially, the contrast in Ritchie's model depends upon prediction. He uses as an example the following joke "Isn't modern technology wonderful? I remember the excitement when we were the first family in our street to have cordless pyjamas" (Arnold Brown, Ritchie 2004: 
101). Obviously the collocations would predict phones/telephones. Ritchie captures this by pointing out that it may be helpful to include details or choose phrasings which support or suggest the 'non-hidden' (more OBVIOUS) interpretation. Phrasings which predict collocations and meanings can be more thoroughly investigated using the concept and theory of lexical priming.

\section{The theory of lexical priming}

Tabossi explains and illustrates the notion of priming as follows:

When a word is recognised (i.e. its entry becomes activated), activation automatically spreads to entries close to it ... This phenomenon, often referred to as lexical priming, is reflected in the shorter time required to identify a target (e.g. nurse) when it follows a word (prime) semantically related to it (e.g. doctor).

(Tabossi 1989: 27)

Highly predictable completions tend to be responded to faster than less predictable ones, so that, for example, the following completions evoke progressively slower responses: "She cleaned the dirt from her shoes/hands/terms" (Tabossi 1989: 28-9).

Michael Hoey's developed this theory in Lexical Priming (2005), which begins with the following examples:

(1) In winter Hammerfest is a thirty-hour ride by bus from Oslo, though why anyone would want to go there in winter is a question worth considering.

(2) Through winter, rides between Oslo and Hammerfest use thirty hours up in a bus, though why travellers would select to ride there then might be pondered.

Though both grammatical, only (1) sounds normal, because in (2) the collocations are unusual. Hoey (2005: 6-7) demonstrates that it is the frequency of normal collocations which make (1) more natural than (2), by presenting collocational frequency data from his own corpus, and concludes that the following collocational sequences are relatively predictable:

$$
\begin{aligned}
& \text { thirty - hour - ride - by - bus - from } \\
& \text { though-why - anyone-would-want-to-go- there }
\end{aligned}
$$

According to Hoey such collocational patterns can be explained by the fact that every word is mentally primed for collocational use. Hoey (2005: 11) claims:

The notion of priming ... assumes the mind has a mental concordance of every word it has encountered, a concordance which has been richly glossed for social, physical, discoursal, generic and interpersonal context. The mental concordance is accessible and can be processed in much the same way that a computer concordance is, so that all kinds of patterns, including collocational patterns, are available for use.

It is worth noting that priming can be recursive, so that collocational phrases activate their own primings.

Hoey puts forward nine priming hypotheses. Every word representing a lexical item has the following primings: (A) collocates; (B) associations with semantic sets, e.g. [NUMBER] hour [JOURNEY] ; (C) associations with pragmatic functions, e.g. sixty occurs with markers of approximation, about, around, etc.; (D) textual semantic associations, which participate in predictable semantic relations, e.g. sixty, tends to participate in contrast or as a problem in problem-solution structures; (E) grammatical functions or colligations, e.g. pondered occurs 
much less frequently as a past participle after the verb be in a passive construction than as simple past tense; (F) association with grammatical categories, e.g. bully and blackmail tend to insert into the matrix PERSON $(\mathrm{S})+B E+$ blackmailed/bullied + into $+\mathrm{V}$-ing; $(\mathrm{G})$ textual collocations creating cohesion-some words form cohesive chains more often than others; (H) textual colligations predicting likely positioning in the discourse, e.g. in his data, 208 of 307 instances of sixty are in the Theme, 200 are sentence-initial, 9\% are the first word of the text.

Because ambiguity is so important to humour, the most relevant priming hypothesis for humour theory is:

When a word is polysemous, the collocations, semantic associations and colligations of one sense of the word differ from those of its other senses.

This builds on the insights of John Sinclair (1991: chapter 3), who discovered that different meanings of ambiguous words tend to correlate with different forms, different grammatical categories and grammatical structures. Take the word forms decline, declines, declining, declined. DECLINE 'refuse' is transitive in 33\% of the tokens in Sinclair's data (though passives are non-existent). $43 \%$ are followed by infinitives, e.g. to do so. 9 "intransitive" clauses with declined are text-transitive, i.e. have their objects occurring earlier in the text. With the meaning 'refuse', $75 \%$ of tokens have the form declined, and $92 \%$ of these are simple past tense, only $8 \%$ past participles.

By contrast, when the meaning of declined is 'become smaller' or 'deteriorate' $50 \%$ of the time it occurs in the present perfect tense as past participle. So, typical instances of decline would be:

I declined the invitation.

I declined the invitation to spend a holiday with them

She invited me, but I declined.

Standards of English have declined over the years.

The numbers of students going to Australia have declined.

(Sinclair 1991: 44-51)

The conclusion that Sinclair and Hoey reach is that ambiguity in discourse is a rarity. Tabossi puts it as follows:

One might assume that the dominant meaning of the ambiguity has already achieved activation from context prior to its occurrence, in such a way that, as soon as the word is actually presented, its primed meaning will become available, whereas its subordinate meaning will be inhibited.

(Tabossi 1989: 38)

Hoey therefore elaborates the following sub-hypotheses, that in cases of potential ambiguity:

The rarer sense of the word will be primed to avoid the collocations, semantic associations and colligations of the more common sense of the word.

Where two senses of a word are as frequent as each other they will both avoid each other's collocations, semantic associations and colligations.

Where 1) and 2) do not apply the result will be humour, ambiguity, or a new meaning combining the two senses.

The sub-hypothesis 3) is obviously important in explaining humour. Not only is it the case that "deliberate ambiguity will be shown to underlie much, if not all, of verbal humour" (Raskin 1985: xiii), but as Ritchie (2004: 94-95) elaborating on his forced reinterpretation model points out, "The need for there to be a 'most OBVIOUS' reading of any ambiguous 
forms is also fairly conventional (if not fully understood theoretically)". I hope this article can use priming theory to explain the obviousness in Ritchie's model.

Simpson (2003) has already started to develop a theory of humour based upon priming. A good example of how his theory of satire works is the following:

\section{OLYMPIC DRUG SHOCK}

By our Olympics Correspondent Anna Bolic-Steroid

THE entire Olympic movement reacted with shock and dismay today after a leading athlete arriving in Sydney was found not to be taking drugs.

"I stupidly thought I could win by sticking to the rules," said the disgraced star. "I now accept that training hard and eating sensibly was not the way to win and that I've let everyone from my pharmacist to my drug dealer down."

(From Private Eye 1011; September 2000; p.22)

Here, the priming (set-up) echoes a specific discourse schema (genre) with its associated topic-i.e. a tabloid news report about illegal drug-taking disgracing an athlete. This echoic phase is fractured by a dialectic based on incongruity, which creates an oppositional irony through the use of the unpredictable "not" - "was found not to be taking drugs" (Simpson 2003: 135-6).

\section{Jokes and lexical priming: some case studies}

So let's test the hypothesis that overriding priming can account for humorous effects, by looking at 7 examples of humorous utterances.

1) As he uttered the last word he dropped his voice, and she didn't quite catch it.

This joke, or unintended humour, depends upon the ambiguity of both drop and catch. Firstly we can investigate priming by the association with semantic sets of the collocation quite catch. From the following evidence it would appear that this can be identified as [UTTERANCE /WORD][IDEA][PERCEPTION], as in most of the examples it has the abstract metaphorical meaning 'hear', though there are a few examples of the association [COMPETITOR]. Since "word" precedes "quite catch" in the joke, then this meaning is reinforced.

\section{UTTERANCE/WORD}

The wind strengthened as Lirael mulled over what she'd heard, so she couldn't quite catch the next bit of conversation.

What he shouted, we couldn't quite catch.

He hisses something in Spanish that I don't quite catch

She ........ murmured something he couldn't quite catch

He said something in Spanish that I couldn't quite catch with all the engine noise.

She muttered something, and although I didn't quite catch it, I thought she said, 'How very interesting'.

She added something else, but it was half under her breath and I didn't quite catch it.

I'm sure the class didn't quite catch it the first time around.

I'd like to ask you er I didn't quite catch what you were saying about the Hans Holbein.

Hi MX erm I was just phoning I didn't quite catch all of what one of your previous callers has said.

You were saying that there was also erm an extra incentive what was that ... I didn't quite catch that.

Danny didn't quite catch it all 
I am about to say no when the santero says a few words I don't quite catch to the woman. He murmured something sympathetic that she didn't quite catch.

\section{NAME}

I didn't quite catch your name.

"My name ... ah ... my name is ... "My clients come from all over the world-Germany, Singapore, Argentina, France, even once from Mongolia-but still I couldn't quite catch the wavering rhythm of his speech when he said his name.

Before me stood the god Ramalinghaswara ......and a dark goddess with a name I couldn't quite catch .

Farkas didn't quite catch their names, but decided it didn't matter.

I didn't quite catch anybody's name.

He turns to us, but we don't quite catch his name over the scratchy opening bars

\section{PERCEPTION}

THE little boy, even standing on his tippy toes, couldn't quite catch a glimpse of his mum.

There was something else, something Kelly didn't quite catch about her that was disturbing nonetheless ... a slackness, perhaps

There was a telegram from Wakeman lying on his desk, but in his haste to read it - upside down, of course - McLaren didn't quite catch the context or the date Wakeman's telegram had been sent

\section{COMPETITOR}

Utah twice cut a 19-point lead to three, but couldn't quite catch up.

The kids couldn't quite catch the old-timer in a very fast women's 400 meters ....

"I had a chance there at the end, but couldn't quite catch him," Campbell said.

I didn't quite catch Prilukov and qualified third-fastest, but that didn't matter .....

Table 1. Word-sketch data for Subject of drop

\begin{tabular}{|l|l|l|}
\hline subject & $\underline{16226}$ & 4.3 \\
\hline jaw & $\underline{263}$ & 8.57 \\
\hline penny & $\underline{171}$ & 8.03 \\
\hline temperature & $\underline{313}$ & 7.78 \\
\hline mouth & $\underline{163}$ & 7.0 \\
\hline index & $\underline{166}$ & 6.93 \\
\hline bomb & $\underline{190}$ & 6.4 \\
\hline prosecutor & $\underline{109}$ & 6.34 \\
\hline rating & $\underline{97}$ & 6.25 \\
\hline share & $\underline{275}$ & 6.21 \\
\hline wind & $\underline{150}$ & 6.18 \\
\hline warplane & $\underline{36}$ & 6.02 \\
\hline
\end{tabular}

\begin{tabular}{|l|l|l|}
\hline subject & $\underline{\mathbf{1 6 2 2 6}}$ & 4.3 \\
\hline plane & $\underline{131}$ & 5.96 \\
\hline puck & $\underline{38}$ & 5.92 \\
\hline helicopter & $\underline{71}$ & 5.86 \\
\hline price & $\underline{452}$ & 5.85 \\
\hline sale & $\underline{246}$ & 5.69 \\
\hline revenue & $\underline{99}$ & 5.65 \\
\hline average & $\underline{68}$ & 5.64 \\
\hline rate & $\underline{360}$ & 5.57 \\
\hline attendance & $\underline{35}$ & 5.56 \\
\hline voice & $\underline{157}$ & 5.55 \\
\hline
\end{tabular}


Table 2. Collocation candidates drop $0+2$

\begin{tabular}{|l|l|l|l|}
\hline & & Freq & T-score \\
\hline$\underline{\mathrm{p}} / \underline{\mathrm{n}}$ & goal & 879 & 29.258 \\
\hline$\underline{\mathrm{p}} / \underline{\mathrm{n}}$ & points & 494 & 21.492 \\
\hline $\mathrm{p} / \underline{\mathrm{n}}$ & dead & 408 & 19.679 \\
\hline$\underline{\mathrm{p}} / \underline{\mathrm{n}}$ & ball & 386 & 19.100 \\
\hline$\underline{\mathrm{p}} / \underline{\mathrm{n}}$ & bombs & 346 & 18.509 \\
\hline $\mathrm{p} / \underline{\mathrm{n}}$ & percent & 360 & 18.264 \\
\hline$\underline{\mathrm{p}} / \underline{\mathrm{n}}$ & charges & 329 & 17.727 \\
\hline$\underline{\mathrm{p}} / \underline{\mathrm{n}}$ & blood & 329 & 17.651 \\
\hline $\mathrm{p} / \underline{\mathrm{n}}$ & shot & 299 & 16.532 \\
\hline $\mathrm{p} / \underline{\mathrm{n}}$ & sharply & 260 & 16.036 \\
\hline$\underline{\mathrm{p}} / \underline{\mathrm{n}}$ & water & 278 & 15.582 \\
\hline $\mathrm{p} / \underline{\mathrm{n}}$ & zone & 245 & 15.507 \\
\hline$\underline{\mathrm{p}} / \underline{\mathrm{n}}$ & dramatically & 238 & 15.341 \\
\hline $\mathrm{p} / \underline{\mathrm{n}}$ & shots & 220 & 14.596 \\
\hline$\underline{\mathrm{p}} / \underline{\mathrm{n}}$ & bombshell & 200 & 14.129 \\
\hline$\underline{\mathrm{p}} / \underline{\mathrm{n}}$ & cents & 203 & 14.003 \\
\hline $\mathrm{p} / \underline{\mathrm{n}}$ & four & 253 & 13.832 \\
\hline$\underline{\mathrm{p}} / \underline{\mathrm{n}}$ & three & 292 & 13.828 \\
\hline$\underline{\mathrm{p}} / \underline{\mathrm{n}}$ & demand & 192 & 13.395 \\
\hline $\mathrm{p} / \underline{\mathrm{n}}$ & prices & 194 & 13.257 \\
\hline$\underline{\mathrm{p}} / \underline{\mathrm{n}}$ & nearly & 194 & 13.178 \\
\hline$\underline{\mathrm{p}} / \underline{\mathrm{n}}$ & hints & 172 & 13.077 \\
\hline & & \\
\hline
\end{tabular}

\begin{tabular}{|l|l|l|l|}
\hline$\underline{\mathrm{p}} / \underline{\mathrm{n}}$ & plans & 191 & 12.953 \\
\hline$\underline{\mathrm{p}} / \underline{\mathrm{n}}$ & anchor & 162 & 12.683 \\
\hline$\underline{\mathrm{p}} / \underline{\mathrm{n}}$ & significantly & 156 & 12.348 \\
\hline$\underline{\mathrm{p}} / \underline{\mathrm{n}}$ & case & 191 & 12.060 \\
\hline$\underline{\mathrm{p}} / \underline{\mathrm{n}}$ & open & 178 & 12.057 \\
\hline$\underline{\mathrm{p}} / \underline{\mathrm{n}}$ & last & 290 & 11.921 \\
\hline$\underline{\mathrm{p}} / \underline{\mathrm{n}}$ & oil & 160 & 11.911 \\
\hline$\underline{\mathrm{p}} / \underline{\mathrm{n}}$ & head & 180 & 11.481 \\
\hline$\underline{\mathrm{p}} / \underline{\mathrm{n}}$ & sales & 150 & 11.440 \\
\hline$\underline{\mathrm{p}} / \underline{\mathrm{n}}$ & further & 158 & 11.425 \\
\hline$\underline{\mathrm{p}} / \underline{\mathrm{n}}$ & straight & 145 & 11.385 \\
\hline$\underline{\mathrm{p}} / \underline{\mathrm{n}}$ & goals & 143 & 11.353 \\
\hline$\underline{\mathrm{p}} / \underline{\mathrm{n}}$ & price & 152 & 11.118 \\
\hline$\underline{\mathrm{p}} / \underline{\mathrm{n}}$ & passes & 128 & 11.075 \\
\hline$\underline{\mathrm{p}} / \underline{\mathrm{n}}$ & all & 360 & 10.714 \\
\hline$\underline{\mathrm{p}} / \underline{\mathrm{n}}$ & five & 163 & 10.604 \\
\hline$\underline{\mathrm{p}} / \underline{\mathrm{n}}$ & leaflets & 108 & 10.360 \\
\hline$\underline{\mathrm{p}} / \underline{\mathrm{n}}$ & guard & 109 & 10.095 \\
\hline$\underline{\mathrm{p}} / \underline{\mathrm{n}}$ & hands & 125 & 10.026 \\
\hline$\underline{\mathrm{p}} / \underline{\mathrm{n}}$ & rain & 107 & 9.997 \\
\hline$\underline{\mathrm{p}} / \underline{\mathrm{n}}$ & opposition & 112 & 9.957 \\
\hline$\underline{\mathrm{p}} / \underline{\mathrm{n}}$ & voice & 116 & 9.823 \\
\hline & & \\
\hline
\end{tabular}

Table 3. Collocation candidates drop +10

\begin{tabular}{|l|l|l|l|}
\hline & & $\underline{F r e q}$ & $\underline{\text { T-score }}$ \\
\hline$\underline{\mathrm{p}} \underline{\mathrm{n}}$ & caught & 104 & 10.196 \\
\hline$\underline{\mathrm{p}} \underline{\mathrm{n}}$ & catches & 90 & 9.487 \\
\hline$\underline{\mathrm{p}} / \underline{\mathrm{n}}$ & catch & 66 & 8.122 \\
\hline$\underline{\mathrm{p}} \mathrm{\underline { \textrm {n } }}$ & catching & 12 & 3.463 \\
\hline$\underline{\mathrm{p}} \mathrm{\underline { \textrm {n } }}$ & slip & 10 & 3.161 \\
\hline
\end{tabular}

We only have one instance of quite catch with a physical object:

"I didn't quite catch that ball, that's why I came up a little short.

We also need to consider the priming of drop. Drop frequently collocates with voice with the meaning 'decrease the volume of' either as colligating subject, as in the word-sketch data in Table 1, or as a following one or two words after drop, as in Table 2. However, these semantic set associations and collocational primings compete with other primings for drop. In Table 2, we already see that drop often has the literal meaning 'cause to fall', as ball and bombs are very common collocates. In Table 3, the most frequent collocates 10 places after the node drop are to do with literal catching (slip referring to a position in cricket where the ball is often caught to dismiss a batter). Thus priming for the literal meaning is strong enough to suggest a literal meaning for "drop" and "catch" creating a secondary humorous interpretation.

2) Some nuns are renovating a church and getting very hot. The Mother Superior suggests they take off their clothes and work naked. The nuns agree, but bolt the church door as a precaution. 
They've all stripped down when there's a knock at the door. "Who is it?" says the mother Superior.

A voice replies "It's the blind man!"

The Mother superior opens the door and the man says, "Nice tits, Sister. Where do you want these blinds?"

(Carr and Greeves 2006: 276)

Firstly, we can consider the grammatical function priming-blind occurs almost exclusively as a premodifying adjective not premodifying noun after the definite article, as in Table 5. Table 4 also gives us the semantic set association for the noun heads following it: there is no association with blinds, in the sense of window coverings. Blind either has a metaphorical meaning as in blind date/obedience/faith/adherence or a metonymic meaning is in blind alley/rage/drunk based on the literal meaning 'sightless'; or if it has this literal meaning as in blind beggar/sheik/cleric/golfer/watchmaker/man. It is not surprising, therefore that concordance data for the collocation blind man never gives an example of the "window covering' meaning.

Even blind men rarely err in pointing out a compass bearing

Maybe there is a blind man who would be happy if you would read the newspaper

......writing a letter for a blind man,

'Well, a blind man on a galloping horse can see there's summat wrong .....

Hillsden fingered the newspapers in the way a blind man touches the sleeve of a long-lost friend.

He had run his hand over his tender face like a blind man seeking to identify a stranger.

a blind man 's natural reaction to a sudden stillness

Bernard's face had a shuttered look, like that of a blind man. He was staring down at the table .....

Like a blind man guided across a road, he had been led .....

'It's what I call blind man 's buff.

The grammatical function priming and the collocational priming, therefore both rule out the 'window covering' meaning. However, blinds in the plural only ever occurs with this meaning, so this priming for 'sightless' is completely overridden, quite apart from the fact that the blind man can obviously see, as his comment on the sister's breasts indicates.

3) I once shot an elephant in my pyjamas. How he got into my pyjamas I'll never know.

(Groucho Marx in Animal Crackers)

There are 7370 hits for elephant in the corpus, but if these lines are filtered $0--+6$ there is no occurrence of pyjamas. This then, is a completely unusual collocation. The word-sketch data for prepositional phrases following elephant is given in Table 5.

What about the priming for the phrase in my pyjamas? We note grammatical category association priming according to the following syntactic pattern: $I+$ verb denoting a material process of movement + adverbial + in my pyjamas. 
Table 4. Word-sketch data for blind as premodifier

\begin{tabular}{|l|l|l|}
\hline modifies & $\underline{6434}$ & 3.5 \\
\hline alley & $\underline{158}$ & 8.8 \\
\hline date & $\underline{58}$ & 8.09 \\
\hline eye & $\underline{1157}$ & 7.97 \\
\hline date & $\underline{339}$ & 7.42 \\
\hline spot & $\underline{318}$ & 7.39 \\
\hline drunk & $\underline{54}$ & 7.36 \\
\hline obedience & $\underline{41}$ & 7.35 \\
\hline faith & $\underline{168}$ & 7.22 \\
\hline panic & $\underline{65}$ & 6.95 \\
\hline beggar & $\underline{28}$ & 6.75 \\
\hline trust & $\underline{99}$ & 6.39 \\
\hline rage & $\underline{40}$ & 6.26 \\
\hline adherence & $\underline{17}$ & 6.23 \\
\hline fury & $\underline{27}$ & 6.23 \\
\hline loyalty & $\underline{39}$ & 6.21 \\
\hline placebo & $\underline{21}$ & 6.19 \\
\hline
\end{tabular}

\begin{tabular}{|l|l|l|}
\hline modifies & $\underline{6434}$ & 3.5 \\
\hline sheik & $\underline{12}$ & 5.8 \\
\hline devotion & $\underline{16}$ & 5.72 \\
\hline bend & $\underline{10}$ & 5.43 \\
\hline mouse & $\underline{23}$ & 5.35 \\
\hline watchmaker & $\underline{8}$ & 5.3 \\
\hline width & $\underline{11}$ & 5.28 \\
\hline Zimbabwean & $\underline{8}$ & 5.13 \\
\hline cleric & $\underline{18}$ & 5.06 \\
\hline prejudice & $\underline{13}$ & 4.98 \\
\hline golfer & $\underline{13}$ & 4.93 \\
\hline person & $\underline{144}$ & 4.82 \\
\hline stupidity & $\underline{7}$ & 4.77 \\
\hline arrogance & $\underline{8}$ & 4.76 \\
\hline optimism & $\underline{12}$ & 4.72 \\
\hline man & $\underline{569}$ & 4.64 \\
\hline
\end{tabular}

Table 5. Elephant collocations

\begin{tabular}{|l|l|l|}
\hline captivity & $\underline{9}$ & 7.24 \\
\hline zoo & $\underline{7}$ & 5.83 \\
\hline middle & $\underline{6}$ & 3.28 \\
\hline room & $\underline{32}$ & 2.32 \\
\hline
\end{tabular}

However when I eventually returned to the bedroom in my pyjamas ....

I wish I'd walked through the night in my pyjamas .

I went downstairs in my spotted pyjamas, the legs rolled up above the knee, in a jeu d'esprit.

I was ready to go out to them in my pyjamas this morning.

I went to class in my pyjamas like everyone else, and insisted to my classmates that I was just another student.

I had to leave the house like this, in my pyjamas.

"I was a bit sleepy at first but I went straight out in my pyjamas ," she said.

She says: "I've gone to clubs in my pyjamas and everyone's like, Hey, cool!"

I will just put my hair up and go in my pyjamas.

There are no examples of material process verbs of action like the shoot in the joke, except

There are no mirrors here and I can come down and do my exercise in my pyjamas.

And this is not a typical material process since the "do" has exercise as a Range not a Goal.

There are several examples of in my pyjamas as complement of the verb to be:

"I was in my pyjamas and I left with nothing else," he says. 
I'm in my pyjamas and I run into the street and all I can see is smoke.

I feel comfortable around the camera and just act natural unless I'm in my pyjamas and then I hide.

I was up in the middle of the night in my pyjamas bailing the water out.

Or as an adverbial for more or less stative or relational verbs

I have a clear recollection of being nine years old and sitting in my pyjamas watching the Ten O'Clock News.

I spent most of my life in my pyjamas or, if I had to go out, old jeans.

There are also a number of sentences where in my pyjamas postmodifies me.

I were dying to go to $t$ ' toilet but I didn't want them to see me in my pyjamas so I didn't go.

The sight of me in my pyjamas should scare anyone off.

We went in to meet the hospital directors, me still in my ward pyjamas and dressing-gown.

These last three examples highlight an obvious point - that the referent of the 1st person pronouns are almost always what in my pyjamas modifies, or the first person pronoun is always within the scope of the modifying phrase, generally the $I$ at the beginning of the clause. There is only one exception to this, where it immediately postmodifies "your dick".

If I wake up with your dick in my pyjamas, Andy-boy, I'll cut it off.

We might, therefore, introduce a further kind of priming, priming for scope of modification, and it is the over-riding of this which is necessary for the Groucho Marx gag.

\section{4) POLICE CAN'T STOP GAMBLING}

The priming in this humorous headline is quite similar to the previous example. The primed meaning is 'Police can't stop themselves gambling', as can be seen from the following concordance evidence where the subject of stop gambling is a previously identified participant, either the surface subject of the main clause or the underlying subject of the infinitive clause.

At one stage Mercy stopped gambling for two months.

'And will I ever be able to stop gambling?

'I stopped drinking, I stopped gambling, I stopped doing drugs, I've tried my hardest

MARIO MELCHIOT has told his Chelsea team-mates to stop gambling with their chances

of success.

It's time the Government stopped gambling with our children's education

Maybe if you lost once in a while you'd stop gambling.

Of course, they must win sometimes; otherwise, they'd stop gambling, free junkets or no.

even if, on the off chance he does win, he stops gambling .

"He had stopped gambling and had been out of the program for three months when he died,

He has since received treatment, stopped gambling and put his life back together.

It showed that 80 percent of them stopped gambling there.

she vowed she would stop gambling and do anything Grady wants her to do

One source said the NHL wants to verify that Roenick stopped gambling in January

....had he not stopped gambling at a certain point, the money would not have come to us.

people too sick to stop gambling even on a drink break.

Sam and Mary try to persuade a high-roller to dump his fiancée because she wants him to stop gambling

"" Never, never, never "have her two children urged her to stop gambling, she says. 
The ban has caused some smokers to stop gambling, according to Olynik. The intended meaning of the headline is presumably that police can't stop some other people gambling. It may be that the abbreviated grammar of headlines is what leads to the ambiguity here.

5) I can still enjoy sex at 75. That's because I live at 76 and it's very close.

At [+NUMBER] is a time adverbial prepositional phrase after still, except when percentages are mentioned:

'I thought I played well against Hibs but I feel I'm still only playing at 80 per cent of my potential.

"He is still only running at $\mathbf{8 5}$ per cent," Jones said.

And, globally, its cost-to-income ratio is still high at 60 per cent.

'Power's still at 90 percent," Furness said.

Analysts bill voice-support service at 20 per cent more than e-mail services, and interactive chat still higher at 70 per cent.

Apart from these examples the priming association is with the semantic set of [AGE], certainly not [HOUSE NUMBER]. There is, incidentally, a textual semantic association of unexpected comparison with a younger age when this structure is used, which does not apply to the unlikely meaning of house number. These two facts are obvious from the following concordance lines:

\section{STILL + COMPLEMENT}

The lady still a champ at 75 By Marie Foy mfoy@belfasttelegraph.

Play goes on for Saddam, still the survivor at $\mathbf{6 5}$ the author [Watson]) is still, at 75, at the top of his game.

As for Advani, at 70 he is still younger than the future president of the bjp.

"Proud Steele, still sprightly at 60, lines up for the Broughty Ferry side

Bette Midler: still saucy at $\mathbf{6 0}$

"Still sexy at 70, Nichols dabbed tears from her eyes

The title does not go to Scott Reiniger's father, also called Scott and still alive at 80,

Still a hot mama at 70, Henderson prefers applying her own makeup

Moore, at 65, still looks like, well, Mary.

(to explain why, at 70, he can still be hailed as a rising star)

\section{STILL + VERB}

TINA still rocks at $\mathbf{6 5}$ - and that in itself is impressive.

a man who at 85 still skis and climbs mountains

"She also taught me how to do the splits, which she could still do at $\mathbf{7 0 , " s h e ~ e x p l a i n e d . ~}$

As president, at 70, he was still making regular visits to Bibby Line Group ventures

She also chats to fashionista Jibby Beane, still modelling at 60

Valerie Grove finds Edward Fox still capturing hearts at $\mathbf{6 5}$

"Director Franco Zeffirelli, still sparking glamorous ideas at 80

Richard Knecht, still exercising at 90

Some lines have the structure referring to the future and, because they are negative, illustrate a textual semantic association of potential contrast, rather than comparison:

Act now or you won't still be smiling at $\mathbf{6 5}$;

If you don't want to be still slogging away at 70, here's what you have to do.

'I don't want to be still working at $\mathbf{7 0}$ - in fact, I'd like to retire early 
The following lines are not describing people and their actions but government policies or regulations

people now are living into their 80-90s yet social security still kicks in at $\mathbf{6 5}$

What would happen if the avg person lived to 100-110 yet social security still kicked in at $\mathbf{6 5}$ ?

6) "I felt like a man trapped in a woman's body. Then I was born"

(Chris Bliss, Carr and Greeves 2006: 61)

The textual semantic association of a man/woman trapped in a ... body is always to express an identity problem as the word trapped suggests. Generally this is to do with sex role or gender identity, either women wishing to be men:
'You know how some people will say, 'I always felt that I was a man trapped in a woman's body"
to think of themselves as Elizabeth I did, as a man trapped in the puny body of a woman?
"Effectively she's been a man trapped in a woman's body, and she's had enough of it.
'I thought I was a man trapped in a woman's body," says the 53-year-old photographer, who has been female for ten years.
I often feel that I am a gay man trapped in this body " - Pamela Anderson in Jane magazine.

Or men wishing to be women:

Jansen, had long felt he was a woman trapped in a man 's body .

and then other people might say 'I always felt I was a woman trapped in a man's body".

It seems only a matter of time before an England player appears on Esther to announce he is a woman trapped in a man 's body

Pandey plays an out-of-work gotipua who believes that he is a woman trapped in a man 's body.

After 25 years of marriage a hubby confesses he is a woman trapped in a man 's body .

A transsexual man, for example, feels that he is a woman trapped in a man 's body .

The former had the soul of a woman trapped in the body of a man;

'Because he is a woman trapped in a man 's body .

He said: "I describe myself as a lesbian trapped in a man 's body.

Though sometimes the problem is not as simple as that:

I'M a straight man trapped in a gay bloke's body and I can't face the rest of my life like this.

Often, later in the text, the solution is introduced in terms of sex change surgery, here in the same sentence:

HAYLEY said she felt like a woman trapped in a man 's body before the surgery.

At other times the problem is not to do with sex or gender roles but with weight, age or ethnicity, and surprisingly, in our concordance data these all apply to men:

Simon Ings is a fat man trapped in the body of an elf

In short, he is a middle-aged man trapped in the body of a 23-year-old.

Tom Hanks is always cute - a child trapped in a man 's body in Big and then as Forest Gump

Tom Hanks played a boy trapped in a man 's body, and fills his flat with toys and trampolines. as if, an American kid, he'd woken to discover himself trapped in a middle-aged man 's body ,. 
Every one of the species presents himself as a secretly ambitious man trapped in the body of a hapless one.

Far from feeling like a Chinese man trapped in a Westerner's body

Again, a solution might be suggested in some cases but less frequently than when the problem is gender role.

MY husband got a tattoo on his bum because he hates feeling like a young man trapped in an old body

The solution is never, however, to be born, but to change the body in some way.

These six examples give further evidence, besides that which I already proferred in Meaning and Humour (Goatly: 2012), for the ways in which lexical priming can help to explain the mechanisms of humour. But I would like to end with what appears to be a counter example, though admittedly an example of unintentional humour.

7) Four people and Congressman Ryan were killed.

(US newscaster, Tibballs 2006: 511)

The humour here would seem to derive from the implicature that Congressman Ryan does not belong in the category PERSON ("people"). And indeed, some of our concordance lines give evidence that people and [Y] prime for contrasting mutually exclusive categories. These categories may be inanimate, if not abstract:

needing 50 people and a fleet of chase boats just to go sail testing for the afternoon.

The fibreglass boat was being weighed down by .... three people and a range of equipment.

"A billion people and a little island, which has done almost nothing for me

$\mathrm{He}$ is in charge of 28,000 people and a budget of $£ 2.5$ billion a year.

The spaceship would have carried more than a hundred people and a cargo of thousands of tons this mission might be about to lose some very nice people and a very expensive airplane.

But if you give me 5,000 people and a huge microphone, then I'll be able to talk.

Instead it brought in undesirable people and a lot of illegal activities.

With some 48 million people and a land mass equivalent to France, Ukraine's sheer dimensions make its fate a matter of concern.

Or, especially in news discourse, the pattern is filled by animals of various kinds:

But he also finds other broken-down people and a horse

3 million people and a few billion sheep just ceased to exist!

so people and a few household pets get gnawed into the netherworld by the vermin

The Cryonics Institute has 41 people and a number of pets on ice at the complex.

"When I got this house, I had it in mind to fill it up with a lot of people and a lot of animals,

And especially dogs:

three people and a dog had been rescued from a fire and taken to hospital,

trips which were nothing more than glorious outings for two people and a happy dog.

Thirty-four people and a dog were removed from homes in the city

There was no child restraint in the car the baby was travelling in with four other people and a dog

"In front of 30 people and a couple of dogs," Marc Cable, the Lewes captain, said

I've watched it grow from an acorn, playing to a few dozen people and a stray dog, to ....... 
However, it is quite common for the second category following and to be a hyponym of the first. Unless the implication is that children and babies are not fully people, then this is true of the following:

some twenty people and a host of sticky little children bearing false witness against me Five people and a baby were rescued by a fire engine Two other people and a girl stood nearby, all looking at her.

Certainly in the lines below, there does not seem to be an implication (humorous or otherwise) that the category relationship is anything but a hyponymic one:

And a lot of very good people and a lot of very good social workers are going to be dragged along with this.

... leaving behind a silent room full of people and a stunned and flushed Joanna Brady.

"Usually on a Sunday there are six security people and a few scientists working

I've worked for a lot of people and a lot of editors

but this is a terrific group of people and a good staff.

The 11-year-old Boeing 737-500 was carrying about 120 people and a crew of five.

Given the frequency of the collocational and textual semantic association pattern exemplified in the last 9 lines, it remains something of a mystery why the phrase "Four people and Congressman Ryan" could be interpreted humorously. Whether the priming is stronger for contrasting categories in the passive construction I do not have enough data to investigate. Certainly the desire to make fun of authority figures might induce a priming, psychological, but not based on lexical patterning.

\section{Problems with lexical priming as an explanation of humour}

I have explained priming theory and shown its potential for explaining the unexpectedness necessary in the case of six jokes. But, as the seventh humorously interpreted example showed, lexical priming cannot always explain the mechanisms of humour. Firstly, it is doubtful whether all types of humour depend upon the overriding of priming. Joke 7) primes almost equally for hyponymy and category contrast, so the humour cannot really be explained as an overriding of priming. Take as another instance the following example of unintentional and humorous ambiguity.

8) MARCH PLANNED FOR NEXT AUGUST.

(Bucaria 2004: 291, 299)

This example necessitates backtracking, and therefore lexical priming cannot explain it, if we assume that priming works in a linear fashion.

It may be objected that both 7) and 8) are examples of unintentional humour. But the following is intentional, yet it too seems to test the humour as overriding priming model:

It so happens that if there is any institution which is not susceptible to any improvement whatsoever, it is the house of Lords.

(W.S. Gilbert quoted in Ritchie 2004: 99) 


\section{Summary and conclusion: overriding priming and humour as liberation?}

I began by emphasising the importance of incongruity, unpredictability and ambiguity in theories of verbal humour. I then sketched lexical priming theory, suggesting that the unexpectedness essential to jokes might be fruitfully theorised in terms of the overriding of priming. I demonstrated that, in six jokes or humorous utterances, the unexpectedness and unpredictability of meaning could indeed be explained by the overriding of primings of collocations, semantic set associations, grammatical functions, textual semantic associations, and grammatical category associations, suggesting that the latter could involve a more delicate "scope of modification priming".

Finally I would like to relate the phenomenon of cancelling or overriding priming to the theory of humour as liberation. Freudian humour theory (Freud 1905) is often described as a theory of release or liberation from the psychological tension between the subconscious desires or the id, and the control over these by the superego. Freud suggests that much humour targets sacred, taboo and disgusting objects or topics, because we normally repress our feelings about them. Humour, then, is a temporary carnival, a rebellion against normal prohibitions. Victorian theorists of humour too had stressed not only its psychological release (Spencer 1864), but also its potential for social rebelliousness or liberation. Bain (1865) thought the pleasure in degrading persons of dignity was a liberation from the normal constraints which demand honour and respect.

Can the overriding of primings, then, count as an attempt a social and psychological liberation? It is a truism that language and language use is influenced by two opposing forces, forces for standardization, and forces of variation. If language is a kind of fascism, it is so partly by imposing standards and predictability on language users. Maybe one of the severest kinds of social control is experienced when we are taught our first language, including its primings. Parents, then, and later the academy, and the educational establishment, attempt to exercise their power by compelling conformity. Priming is obviously a centripetal or standardizing force, pushing the language towards conventional collocation and cliché. By contrast, the kinds of humour which override priming can be seen as playful attempts at creativity, as defiance of convention.

\section{References}

Attardo, S. (1994). Linguistic Theories of Humour. Berlin, New York: Mouton.

Attardo, S. (2001). Humorous Texts: A Semantic and Pragmatic Analysis. Berlin, New York: Mouton.

Attardo, S., \& Raskin, V. (1991). 'Script theory revisited: joke similarity and joke representation model'. Humor: International Journal of Humour Research (53/4), pp. 293-347.

Bain, A. (1865). The Emotions and the Will. $2^{\text {nd }}$ edition. Harlow: Longmans.

Carr, J. \& Greeves, L. (2007). The Naked Jape: Uncovering the Hidden World of Jokes. Harmondsworth: Penguin.

Chafe, W. (2007). The Importance of not Being Earnest. Amsterdam: Benjamins.

Chiaro, D. (1992). The Language of Jokes: Analysing Verbal Play. London: Routledge

Freud, S. (1905). Jokes and their Relation to the Unconscious. Leipzig: Deuticke.

Giora, R. (1995). 'On irony and negation'. Discourse Processes 19, pp. 239-264.

Goatly, A. (2012). Meaning and Humour. Cambridge: CUP 
Hoey, M. (2005). Lexical Priming: A New Theory of Words and Language. London: Routledge.

Nash, W. (1985). The Language of Humour. Harlow: Longman.

Raskin, V. (1985). Semantic Mechanisms of Humor. Dordrecht-Boston-Lancaster: D. Reidel.

Ritchie, G. (2004). The Linguistic Analysis of Jokes. London and New York: Routledge.

Simpson, P. (2003). On the Discourse of Satire. Amsterdam: Benjamins.

Sinclair, J. M. (1991). Corpus, Concordance, Collocation. Oxford: Oxford University Press.

Spencer, H. (1864). 'The physiology of laughter', in Spencer, H., Essays: Scientific, Political and Speculative, Second series, New York: D. Appleton.

Tabossi, P. (1989). 'What's in a context?', In David S. Gorfein (ed.) Resolving Semantic Ambiguity. Berlin: Springer Verlag. 25-39.

Tibballs, G. (2006). The Mammoth Book of Jokes. London: Robinson. 